\title{
Managing individual juniper and pinyon infestations with pelleted tebuthiuron or picloram
}

\author{
THOMAS N. JOHNSEN, JR., AND RAYMOND S. DALEN
}

\section{Abstract}

Junipers (Juniperus spp.) and pinyons (Pinus edulis Engelm.) are reinfesting areas from which they have been removed and are encroaching into other areas. Controlling these trees while they are small would help maintain forage production and protect the soils. Individual trees can be controlled by applications of pelleted picloram (4-amino-3,5,6-trichloro-2-pyridinecarboxylic acid) and tebuthiuron $\left\{N\right.$-[5-(1,1-dimethylethyl)-1,3,4-thiadiazol-2-yl\}- $N, N^{\prime}$-dimethylurea\}, but little is known of the comparative effectiveness of these herbicides on junipers and pinyon. We compared pelleted picloram and tebuthiuron on individual alligator juniper $(J$. deppeana Steud.), one-seed juniper [J. monosperma (Engelm.) Sarg.], Utah juniper [ $J$. osteosperma (Torr.) Little], and pinyon. Pellets were applied at 0.7 and $1.4 \mathrm{~g}$ picloram acid equivalent (a.e.) or tehuthiuron active ingredient (a.i.)/ $\mathrm{m}$ of tree height at 3 Arizona and 3 New Mexico locations. Utah juniper and pinyon trees up to 2 $\mathrm{m}$ tall were killed with $0.7 \mathrm{~g}$ picloram a.e. or tebuthiuron a.i./ $\mathrm{m}$ of height. One-seed junipers up to $2-\mathrm{m}$ tall were killed by $0.7 \mathrm{~g}$ tebuthiuron $\mathbf{a . i .} / \mathbf{m}$ of height, but were not by picloram. Neither herbicide killed alligator juniper consistently. Some understory grasses were damaged more by tebuthiuron than by picloram.

Key Words: alligator juniper, one-seed juniper, Utah juniper, pinyon, herbicides, brush control, range improvement

Authors are research agronomist, USDA, Agricultural Research Service, 2000 East Allen Road, Tucson, Arizona 85719; and range improvement specialist (retired), Management and Improvement, Region 3, USDA, Forest Service, Albuquerque, New Mexico 87102, respectively.

We thank the Apache-Sitgreaves, Cibola, Coconino, and Gila National Forests for help with these studies.

Manuscript accepted 24 August 1989.
Junipers (Juniperus spp.) and pinyons (Pinus edulis Engelm.) were cleared from more than 800,000 ha of Arizona and New Mexico rangeland from the 1950's through the 1970's. Presently, junipers and pinyons are reestablishing on many of these areas and encroaching on others (Johnsen and Elson 1979). Managing these trees is of concern, especially on sites with high forage production potential where $85 \%$ or more of the trees are under $2 \mathrm{~m}$ tall (Dalen and Snyder 1987). Killing small junipers and pinyons would help maintain forage production and protect the soil.

Small junipers and pinyons can be killed by treating individual trees with pelleted picloram (4-amino-3,5,6-trichloro-2-pyridinecarboxylic acid) or tebuthiuron $(N$-[5-(1,1-dimethylethyl)-1,3,4-thiadiazol-2-yl]- $N, N$-dimethylurea (Johnsen 1987, Dalen and Snyder 1987). Pelleted picloram has been reported to kill alligator juniper ( $J$. deppeana Steud.) and Utah juniper [J. osteosperma (Torr.) Little] (Johnsen and Dalen 1984), eastern red cedar ( $J$. virginiana L.) (Stritzke and Rollins 1984), redberry juniper ( $J$. pinchotii Sudw.) (Schuster 1976, Ueckert and Whisenant 1982), western juniper ( $J$. occidentalis Hook.) (Young et al. 1982), and singleleaf pinyon ( $P$. monophylla Torr. \& Frem.) (Young and Evans 1976). Pelleted tebuthiuron killed one-seed juniper [ $J$. monosperma (Engelm.) Sarg.], Utah juniper (Johnsen 1977, Clary et al. 1985), and pinyon (Johnsen 1977, McDaniel and WhiteTrifaro 1987), but did not kill western juniper (Britton and Sneva 1981), redberry juniper (Ueckert and Whisenant 1982), or eastern red cedar (Stritzke and Rollins 1984).

Although pelleted picloram and tebuthiuron each kill some juniper and pinyon species, little is known about the herbicides' 
comparative effectiveness. Picloram killed redberry juniper and eastern red cedar but tebuthiuron did not (Ueckert and Whisenant 1982, Stritzke and Rollins 1984). However, tebuthiuron killed more one-seed juniper trees than did picloram (Brock 1985, McDaniel and WhiteTrifaro 1987), but both herbicides killed pinyon equally well (McDaniel and WhiteTrifaro 1987). It is not known if one herbicide may be substituted for the other. Such information is needed because pelleted picloram is currently not available.

This study compares the efficacy of pelleted picloram and tebuthiuron applied to individual alligator juniper, one-seed juniper, Utah juniper, and pinyon. These species are common on southwestern pinyon-juniper rangelands.

\section{Methods and Materials}

Six study locations, 3 in Arizona and 3 in New Mexico, were used (Table 1). Arizona locations were: Cedar Flat, $26 \mathrm{~km}$ east of Camp Verde; Mud Tanks, $16 \mathrm{~km}$ south of Cedar Flat; and Tin Can Draw, $10 \mathrm{~km}$ south of Cedar Flat. New Mexico locations were: Bonito, $16 \mathrm{~km}$ west of Corona; Cooney Prairie, $14 \mathrm{~km}$ west of the Beaverhead Work Center; and Alma Mesa, $19 \mathrm{~km}$ northwest of Glenwood. Elevations were between 1,800 and 2,100 m, except Cooney Prairie was at $2,400 \mathrm{~m}$. The treatment sites were representative of the surrounding areas. The soils were montmorillontic (Table 1) and could adsorb tebuthiuron (Duncan and Scifres 1983) more readily than picloram (Grover 1971). Except for Cooney Prairie, which was undisturbed, the treated sites were cleared of trees 15 to 20 years previously so most of the trees were under $2 \mathrm{~m}$ tall.

Commercially available picloram and tebuthiuron pellets were used. Picloram pellets contained $10 \%$ acid equivalent (a.e.) picloram and tebuthiuron pellets contained $20 \%$ active ingredient (a.i.) tebuthiuron. Pellets were distributed within the canopy dripline around individual trees by sprinkling pellets over the tops of trees less than 2-m tall, and under the canopies of larger trees. Trees received $0.0,0.7$, or $1.4 \mathrm{~g}$ picloram or tebuthiuron $/ \mathrm{m}$ of height. The $1.4 \mathrm{~g} / \mathrm{m}$ rate was commonly being used on control projects in the region.

Plot sizes differed among locations to accommodate differences in tree densities; tree numbers per plot ranged from 21 to 41 , averaging about 25 . Randomized, complete blocks were used with 3 replications, except there were 2 and 4 replications at Alma Mesa and Mud Tanks, respectively.

Responses were determined by annual ocular estimates of percent live canopy reduction and tree mortality. Trees were classed as dead if no live tissue was evident after 3 or more years. Apparent herbicide damage to other plants near treated trees was also recorded.

Data for each species at each location were subjected to separate analyses of variance. Transformation (arc sine) of percentage data did not change statistical interpretations. Treatment means were compared by orthogonal contrasts.

Effects of tree height were determined for each species in 2 ways. First, by determining weighted means and standard errors of the means of tree mortalities by height classes of 0 to 1,1 to 2,2 to 3 , and $3+\mathrm{m}$, with the fixed rate applications of 0.7 or $1.4 \mathrm{~g} / \mathrm{m}$ of height. This identified species in which the ratios of crown height and crown volume change as the tree becomes taller, causing failure to kill taller trees. Then, second, regressions were developed to determine the minimum amount of herbicide per tree needed to kill at least $90 \%$ of the trees in height classes of the species identified as having poor control of the larger trees with the fixed rates. The total amount of herbicide applied to individual trees in each height class with the fixed rates/m of height were correlated with tree height classes having $90 \%$ or more mortality. The regressions aid estimating the total amount of herbicide to purchase for control projects when average tree height, dosage per tree of that height, and the numbers of trees are known, thus helping minimize costs and reduce storage and disposal problems with excess herbicides.

\section{Results and Discussion}

The percentage of alligator juniper, Utah juniper, and pinyon trees killed by picloram and tebuthiuron did not differ significantly $(P=0.05)$ (Table 2). However, tebuthiuron killed significantly $(P=$ $0.01)$ more one-seed juniper trees than did picloram.

Although alligator juniper mortalities following picloram and tebuthiuron applications were similar, they were variable. For example, few alligator junipers were killed at Cooney Prairie, but all were killed at Tin Can Draw (Table 2). Picloram treatment caused mortalities similar to those reported by Johnsen and Dalen (1984) in Arizona. Factors which may have affected alligator juniper mortality include differences in soils, rainfall, application consistency, tree form, and numbers of dormant basal buds. Season of application has not affected the efficacy of tebuthiuron for control of most woody species (Bovey et al. 1985); nor has season of application been reported to influence juniper mortality from pelleted picloram or tebuthiuron.

Utah juniper trees were readily killed by both picloram and tebuthiuron (Table 2). Johnsen and Dalen (1984) reported piclo-

Table 1. Soils, herbicide treatment dates, annual rainfall, and species treated with pelleted picloram and tebuthiuron.

Soil classification

\begin{tabular}{|c|c|c|c|c|c|}
\hline Order & Subgroup and Family & Sites & Date treated & Annual rainfall & Tree species ${ }^{1}$ \\
\hline Alfisols & $\begin{array}{l}\text { Udic Haplustalfs } \\
\text { Fine, montmorillonitic, mesic }\end{array}$ & Bonito & $\begin{array}{c}(\mathrm{mo} / \mathrm{yr}) \\
5 / 79\end{array}$ & $\underset{370}{(\mathrm{~mm})}$ & Jumo, Picd \\
\hline \multirow[t]{3}{*}{ Mollisols } & $\begin{array}{l}\text { Typic Argiustolls } \\
\text { Fine, montmorillonitic, mesic }\end{array}$ & Tin Can Draw & $7 / 80$ & 430 & Jude, Juos \\
\hline & $\begin{array}{l}\text { Vertic Argiustolls } \\
\text { Fine, montmorillonitic, mesic }\end{array}$ & Alma Mesa & $10 / 80$ & 510 & Jude \\
\hline & $\begin{array}{l}\text { Pachic Argiborolls } \\
\text { Fine, mixed montmorillonitic }\end{array}$ & Cooney Prairie & $8 / 79$ & 480 & Jude \\
\hline Vertisols & $\begin{array}{l}\text { Typic Chromusterts } \\
\text { Fine, } \\
\text { montmorillonitic, mesic }\end{array}$ & $\begin{array}{l}\text { Cedar Flat } \\
\text { Mud Tanks }\end{array}$ & $\begin{array}{l}5 / 80 \\
7 / 80\end{array}$ & $\begin{array}{l}430 \\
430\end{array}$ & $\begin{array}{l}\text { Juos } \\
\text { Jude, Juos }\end{array}$ \\
\hline
\end{tabular}

Iude = alligator juniper; Iume = one-seed juniper; Juos = Utah juniper, Pied = pinyon. 
Table 2. Percentage of plants killed by pelleted picloram or tebuthiuron applied at 0.7 or $1.4 \mathrm{~g}$ a.e. or $\mathbf{a . j} . / \mathrm{m}$ of height to individual trees in Arizona and New Mexico.

\begin{tabular}{|c|c|c|c|c|c|}
\hline \multirow[b]{2}{*}{ Species } & \multirow[b]{2}{*}{ Location } & \multicolumn{2}{|c|}{ Picloram } & \multicolumn{2}{|c|}{ Tebuthiuron } \\
\hline & & 0.7 & 1.4 & 0.7 & 1.4 \\
\hline \multirow[t]{2}{*}{ Alligator juniper } & $\begin{array}{l}\text { Alma Mesa }{ }^{1} \\
\text { Cooney Prairie } \\
\text { Mud Tanks } \\
\text { Tin Can Draw }\end{array}$ & $\begin{array}{r}67 \\
24 \\
98 \\
100 \\
\end{array}$ & $\begin{array}{r}95 \\
48 \\
96 \\
100 \\
\end{array}$ & $\begin{array}{c}85 \\
40 \\
81^{*} \\
100 \\
\end{array}$ & $\begin{array}{r}98 \\
73 \\
100^{*} \\
100 \\
\end{array}$ \\
\hline & Mean & 72 & 85 & 76 & 93 \\
\hline \multirow[t]{2}{*}{ Utah juniper } & $\begin{array}{l}\text { Cedar Flat } \\
\text { Mud Tanks } \\
\text { Tin Can Draw }\end{array}$ & $\begin{array}{r}91 \\
100 \\
100 \\
\end{array}$ & $\begin{array}{l}100 \\
100 \\
100\end{array}$ & $\begin{array}{r}95 \\
100 \\
100 \\
\end{array}$ & $\begin{array}{r}97 \\
-- \\
100 \\
\end{array}$ \\
\hline & Mean & 97 & 100 & 98 & 98 \\
\hline One-seed juniper & Bonito & $32 * *$ & $63^{* *}$ & 84 & $98++$ \\
\hline Pinyon & Bonito & 100 & 93 & 98 & 100 \\
\hline
\end{tabular}

***Herbicide rates differ significantly at the 0.05 and 0.01 level, respectively. ++ Herbicides in row differ significantly at the 0.01 level.

Only 2 replications.

iNot tested.

ram killed Utah juniper. Minor differences in soils, rainfall, and month of application (Table 1) did not affect mortality percentages (Table 2).

Pinyon trees were readily killed by both picloram and tebuthiuron (Table 2). Although the results of this study are from a single location, they are similar to those reported elsewhere for pinyons. Pinyon was killed with $0.9 \mathrm{~kg}$ picloram/ha or $1.1 \mathrm{~kg}$ tebuthiuron/ ha in New Mexico (McDaniel and WhiteTrifaro 1987). Additionally, singleleaf pinyon up to $2 \mathrm{~m}$ tall were killed by $0.7 \mathrm{~g}$ picloram/tree in Nevada (Young and Evans 1976).

More one-seed junipers were killed by tebuthiuron than by picloram (Table 2). The current study on one-seed juniper was done at a single location, but the results agree with those reported from New Mexico (McDaniel and WhiteTrifaro 1987), and from Arizona (Brock 1985). Picloram applied at $1.8 \mathrm{~g} / \mathrm{m}$ of height killed small one-seed junipers in another Arizona study (Johnsen and Dalen 1984).

Mortality percentages were generally similar for both applications rates of either herbicide (Table 2). However, $1.4 \mathrm{~g}$ tebuthiuron $/ \mathrm{m}$ was more effective $(P=0.05)$ than $0.7 \mathrm{~g} / \mathrm{m}$ on alligator juniper at Mud Tank. Also, $1.4 \mathrm{~g}$ picloram $/ \mathrm{m}$ was more effective ( $P$ $=0.01$ ) than $0.7 \mathrm{~g} / \mathrm{m}$ on one-seed juniper, which agrees with the findings of Johnsen and Dalen (1984) in Arizona. Both the 0.7 and $1.4 \mathrm{~g} / \mathrm{m}$ rate of either herbicide killed more than $90 \%$ of the Utah juniper and pinyon trees.

Pinyon trees were readily killed with the $0.7 \mathrm{~g} / \mathrm{m}$ rate of either herbicide applied to all tree height classes treated (Table 3). However, juniper mortalities varied among height classes with the fixed application rates per unit of tree height, especially with the taller trees (Table 3). Juniper tree-height to live crown-volume ratios may change as tree height increases, confounding percent mortality means. Johnsen and Dalen (1984) determined linear regressions best estimated lethal dosages of pelleted picloram for small trees as aids for determining the amounts of herbicide needed for control projects. However, their data base included few trees taller than 2.5 $\mathrm{m}$, and the regressions are not useful for stands with many taller trees. Including taller trees in the data base of the current study resulted in determining that exponential regressions best estimated the lowest amount of herbicide needed to kill at least $90 \%$ of the trees of a given height. Such regressions improve the accuracy of estimating how much herbicide is needed for control projects having trees taller than $2 \mathrm{~m}$. This information will help prevent buying excessive amounts of the herbicides, thus saving funds and avoiding problems of storage and disposal of excess herbicide.

Application of 0.7 of either herbicide killed Utah junipers less than $1 \mathrm{~m}$ tall, and $1.4 \mathrm{~g}$ killed trees under $2-\mathrm{m}$ tall, but the amounts needed to kill taller trees differ from the fixed rate amounts (Table 3). A dose of $3.5 \mathrm{~g}$ picloram or $2.9 \mathrm{~g}$ tebuthiuron is needed to kill at least $90 \%$ of the Utah junipers $3 \mathrm{~m}$ tall, as indicated by the regressions: $\mathrm{Y}=0.49 \mathrm{e}^{0.66 \mathrm{X}}(r=0.98)$ for picloram, and $\mathrm{Y}=0.54 \mathrm{e}^{0.56 \mathrm{X}}(r=$ 0.97 ) for tebuthiuron. $Y$ is dosage in $g$ picloram or tebuthiuron, and $X$ is tree height in $\mathrm{m}$.

One-seed junipers were killed by tebuthiuron but not by picloram (Table 2). Application of $0.7 \mathrm{~g}$ tebuthiuron killed trees $1-\mathrm{m}$ tall, and $1.4 \mathrm{~g}$ killed trees $2-\mathrm{m}$ tall, but the amount needed to kill taller trees differed from the fixed rates (Table 3 ). These results agree with McDaniel and WhiteTrifaro (1987), who found oneseed juniper trees under 3-m tall were more readily killed by tebuthiuron than taller ones. The amount of $5.5 \mathrm{~g}$ of tebuthiuron is need to kill at least $90 \%$ of the $3 \mathrm{~m}$ tall one-seed junipers as indicated by the regression: $Y=0.40 \mathrm{e}^{0.87 \mathrm{X}}(\mathrm{r}=0.95)$. Alligator junipers $1 \mathrm{~m}$ tall were usually killed by $0.7 \mathrm{~g}$ picloram or tebuthiuron, but taller trees were poorly controlled by either herbicide (Table 3).

Damage to understory vegetation under or near treated trees was greatest with the $1.4 \mathrm{~g}$ application rates, and most severe the first year after treatment. Little new understory damage was noted 2 years after treatment. Cool-season grasses, such as western wheatgrass [ Pascopyrum smithii (Rydb.) A. Love], appeared to be damaged more than warm-season grasses, such as blue grama [Bouteloua gracilis (H.B.K.) Lag. ex Griffiths].

Picloram usually damaged only plants under the tree canopy; tebuthiuron often damaged plants under and beyond the tree canopy. For example, at Cedar Flat, Mud Tank, and Tin Can Draw, picloram killed grasses under trees only, but tebuthiuron at the 0.7 and $1.4 \mathrm{~g}$ rates killed grasses as far as $2 \mathrm{~m}$ and $3 \mathrm{~m}$ away from the trees, respectively.

Recovery of picloram-damaged understory vegetation was fast-

Table 3. Percentage of trees killed by pelieted picloram or tebuthiuron applied to individual trees of different heights, means \pm standard error of means. ${ }^{1}$

Trees killed (\%) by height class (m)

\begin{tabular}{|c|c|c|c|c|c|c|c|c|c|c|}
\hline \multirow[b]{2}{*}{ Species } & \multirow{2}{*}{$\begin{array}{l}\text { Rate } \\
(\mathrm{g} / \mathrm{m})\end{array}$} & \multicolumn{5}{|c|}{ Picloram } & \multicolumn{4}{|c|}{ Tebuthiuron } \\
\hline & & $0-1$ & $1-2$ & $2-3$ & $3+$ & & $0-1$ & $1-2$ & $2-3$ & $3+$ \\
\hline $\begin{array}{l}\text { Alligator } \\
\text { juniper }\end{array}$ & $\begin{array}{l}0.7 \\
1.4\end{array}$ & $\begin{array}{r}100 \pm 0 \\
95 \pm 10\end{array}$ & $\begin{array}{l}54 \pm 37 \\
68 \pm 33\end{array}$ & $\begin{array}{l}23 \pm 29 \\
58 \pm 32\end{array}$ & $\begin{array}{r}8 \pm 10 \\
25 \pm 43\end{array}$ & & $\begin{array}{r}91 \pm 46 \\
100 \pm 0\end{array}$ & $\begin{array}{l}59 \pm 31 \\
90 \pm 25\end{array}$ & $\begin{array}{l}47 \pm 44 \\
72 \pm 27\end{array}$ & $\begin{array}{l}14 \pm 27 \\
36 \pm 39\end{array}$ \\
\hline $\begin{array}{l}\text { One-seed } \\
\text { juniper }\end{array}$ & $\begin{array}{l}0.7 \\
1.4\end{array}$ & $\begin{array}{l}40 \pm 20 \\
67 \pm 47\end{array}$ & $\begin{array}{l}45 \pm 41 \\
58 \pm 26\end{array}$ & $\begin{array}{r}0 \pm 0 \\
67 \pm 41\end{array}$ & - & & $\begin{array}{l}100 \pm 0 \\
100 \pm 0\end{array}$ & $\begin{array}{r}100 \pm 0 \\
95 \pm 3\end{array}$ & $\begin{array}{r}50 \pm 22 \\
100 \pm 0\end{array}$ & - \\
\hline $\begin{array}{l}\text { Utah } \\
\text { juniper }\end{array}$ & $\begin{array}{l}0.7 \\
1.4\end{array}$ & $\begin{array}{l}100 \pm 0 \\
100 \pm 0\end{array}$ & $\begin{array}{r}98 \pm 2 \\
100 \pm 0\end{array}$ & $\begin{array}{r}60 \pm 20 \\
100 \pm 0\end{array}$ & $\overline{100 \pm 0}$ & 0 & $\begin{array}{ll}100 \pm & 0 \\
100 \pm & 0\end{array}$ & $\begin{array}{l}95 \pm 3 \\
96 \pm 4\end{array}$ & $\begin{array}{l}100 \pm 0 \\
100 \pm 0\end{array}$ & $\begin{array}{r}50 \pm 25 \\
100 \pm 0\end{array}$ \\
\hline Pinyon & $\begin{array}{l}0.7 \\
1.4\end{array}$ & $\begin{array}{l}100 \pm 0 \\
100 \pm 0\end{array}$ & $\begin{array}{r}100 \pm 0 \\
92 \pm 14\end{array}$ & $\begin{array}{l}100 \pm 0 \\
100 \pm 0\end{array}$ & $\overline{100 \pm} 0$ & 0 & $\begin{array}{ll}100 \pm & 0 \\
100 \pm & 0\end{array}$ & $\begin{array}{r}95 \pm 4 \\
100 \pm 0\end{array}$ & $\begin{array}{l}100 \pm 0 \\
100 \pm 0\end{array}$ & $100 \pm 0$ \\
\hline
\end{tabular}


ter than that from tebuthiuron. For example, at Cooney Prairie, grasses under picloram-treated trees recovered fully within 4 years while only half of the grasses under tebuthiuron-treated trees had.

\section{Conclusions}

Pelleted tebuthiuron can be used in place of picloram to kill one-seed juniper, Utah juniper, and pinyon. But neither pelleted herbicide reliably killed alligator juniper taller than $1 \mathrm{~m}$. Tebuthiuron damaged understory plants more than picloram did.

\section{Literature Cited}

Bovey, R.W., R.E. Meyer, L.G. Bouse, and J.B. Carlton. 1985. Seasonal response of woody plants to tebuthiuron pellets. Weed Sci. 33:551-554.

Britton, C.M., and F.A. Sneva. 1981. Effects of tebuthiuron on western juniper. J. Range Manage. 34:30-32.

Brock, J.H. 1985. Control of junipers in north-central Arizona using tebuthiuron, hexazinone and picloram herbicides. Proc. West. Soc. Weed Sci. 38:168.

Clary, W.P., S. Goodrich, and B.M.Smith. 1985. Response to tebuthiuron by Utah juniper and mountain big sagebrush communities. J. Range Manage. 38:56-60.

Dalen, R.S., and W.R. Snyder. 1987. Economic and social aspects of pinyon-juniper treatment-then and now. p. 343-350. In: Proc. PinyonJuniper Conf. (compiler R.L. Everett), USDA Forest Serv., Gen. Tech. Rep. INT-215, Ogden, Utah.

Duncan, K.W., and C. Scifres. 1983. Influence of clay and organic matter of rangeland soils and tebuthiuron effectiveness. J. Range Manage. 36:295-297.
Grover, R. 1971. Absorption by soil colloids and various absorbents. Weed Sci. 19:417-418.

Johnsen, T.N., Jr. 1977. Tebuthiuron in junipers and oaks. Res. Progr. Rep. West. Soc. Weed Sci., p. 19.

Johnsen, T.N., Jr. 1987. Using herbicides for pinyon-juniper control in the Southwest. p. 330-334. In: Proc. Pinyon-Juniper Conf. (compiler R.L. Everett), USDA Forest Service, Gen. Tech. Rep. INT-215, Ogden, Utah. Johnsen, T.N., Jr., and R.S. Dalen. 1984. Controlling individual junipers and oaks with pelleted picloram. J. Range Manage. 37:380-384.

Johnsen, T.N., Jr., and J.W. Elson. 1979. Sixty years of change on a central Arizona grassland-juniper woodland ecotone. USDA Agr. Res. Serv. ARM-W-7.

McDaniel, K.C., and L. WhiteTrifaro. 1987. Selective control of pinyonjuniper with herbicides. p. 448-455. In: Proc. Pinyon-Juniper Conf. (compiler R.L. Everett), USDA Forest Service, Gen. Tech. Rep. INT215, Ogden, Utah.

Schuster, J.L. 1976. Redberry juniper control with picloram. J. Range Manage. 29:490-491.

Stritzke, J.F., and D. Rollins. 1984. Eastern redcedar and its control. Weeds Today 15:7-8.

Ueckert, D.N., G.S. Whisenant. 1982. Individual plant treatments for controlling redberry juniper seedlings. J. Range Manage. 35:419-423.

Young, J.A., and R.A. Evans. 1976. Control of pinyon saplings with picloram or karbutilate. J. Range Manage. 29:144-147.

Young, J.A., R.A. Evans, J.D. Budy, and A. Torell. 1982. Cost of controlling western juniper trees. J. Range Manage. 35:437-442.

NOW

mation in one place on this increasingly important subject. A greater variety of uses for rangeland, a growing world population, plus deeper concerns for the environment make knowledge about insect grazers of rangeland ever more critical. Written to be understood by the average reader, RANGELAND ENTOMOLOGY still contains the extensive bibliography, lists of both common and scientific names, and suggestions for needed research to make it a valuable addition to the scientist's library. The second edition, edited by J. Gordon Watts, has been expanded to 400 pages with state-of-the-art information on insect friends and foes of rangeland plants and animals and the role of integrated pest management.

Range Science Series No. 2, Second Edition, is available for $\$ 19.95$ from the Society for Range Management. Soft cover, sewed. 